\title{
Types of voltage-dependent calcium channels involved in high potassium depolarization-induced amylase se- cretion in the exocrine pancreatic tumour cell line AR4- 2J
}

\author{
CUI ZONG JIE \\ Beijing Agricultural University Faculty of Biological Sci- \\ ences, Beijing 100094, China
}

\begin{abstract}
In the perifused fura-2 loaded exocrine pancreatic acinar cell line AR4-2J pulses of high potassium induced repetitive increases in intracellular calcium. Attached cells when stimulated with high potassium secreted large amount of amylase. High potassium-induced secretion was dependent both on the concentration of potassium and duration of stimulation. High potassium induced increases in intracellular calcium were inhibited by voltage-dependent calcium channel antagonists with an order of potency as follows: nifedipine $>\omega$-agatoxin IVA $>\omega$-conotoxin GVIA. In contrast, the L-type calcium channel antagonist nifedipine almost completely inhibited potassium-induced amylase secretion, whereas the $\mathrm{N}$-type channel antagonist $\omega$-conotoxin GVIA was without effect. The P-type channel antagonist $\omega$-agatoxin IVA had a small inhibitory effect, but this inhibition was not significant at the level of amylase secretion. In conclusion, the AR4-2J cell line possesses different voltage-dependent calcium channels (L, P, $\mathrm{N})$ with the L-type predominantly involved in depolarization induced amylase secretion.
\end{abstract}

Key words: AR4-2J, pancreatic acinar cells, amylase, secretion, calcium channels.

Address all correpondence to: Beijing Agricultural University Faculty of Biological Sciences, Beijing 100094, Tel: 010-6289-1830, Fax: 010-6289-1055, E-mail: bauic@public.bta.net.cn 
AR4-2J is a cell line originally derived from a transplantable, azaserine-induced murine tumour[1, 2], which contains significant amount of amylase and other digestive enzymes. This cell line contains a number of receptor systems: substance P[3], cholecystokinin[4], somatostatin[5, 6], gastrin[7], bombesin [8], muscarinic acetylcholine[8], vasoactive intestinal peptide[9], and amylin receptors[10], which duplicate the major receptor systems in normal pancreatic acinar cells. Therefore AR4-2J is a model widely used for studying mechanisms of exocrine pancreatic secretion.

In contrast to normal pancreatic acinar cells which do not generate voltageactivated ionic currents and therefore are electrically non-excitable[11, 12], AR4-2J cells have been shown to possess voltage-activated $\mathrm{K}^{+}, \mathrm{Na}^{+}, \mathrm{Ca}^{2+}$ channels[13], therefore this cell line also offers a convenient model for the study of excitable cells. Studies by Wiedenmann and coworkers found that this cell line contains small secretory vesicles $(40-80 \mathrm{~nm})$ that store classical neurotransmitters glycine and GABA. Immunocytochemical studies confirmed the existence of specific markers for these small vesicles: synaptophysin and S.V.2[14, 15]. In addiction, high potassium depolarization stimulated GABA release in this cell line[16].

Pharmacological and molecular biological studies identified the following voltagedependent calcium channels: L, N, T, P, Q and R[17, 18]. The present study aimed to identify which of the above types of voltage-dependent calcium channels exist in AR4-2J cells by pharmacological means and found that the L-type predominated and it was solely responsible for depolarization induced amylase secretion.

\section{MATERIALS AND METHODS}

\section{Cell culture}

AR4-2J was purchased from American Type Culture Collection (Rockville, Maryland, USA). The cells were maintained in Leibovitz L- $15 / \mathrm{CO}_{2}$ medium (Gibco) supplemented with vitamins, glutamine $(2 \mathrm{mM})$, glucose $(44 \mathrm{mM})$, penicillin/ streptomycin $(50 \mathrm{U} / \mathrm{ml})$, and foetal calf serum (20\%, Gibco) at $37^{\circ} \mathrm{C}$ in a humidified $95 \% \mathrm{O}_{2} / 5 \% \mathrm{CO}_{2}$ atmosphere[19]. Cells were fed daily.

\section{Amylase secretion}

AR4-2J cells were subcultured in 24-well plate for 3 days. On day 3, wells were rinsed with modified Ringer's buffer (composition in $\mathrm{mM}$ : $\mathrm{NaCl} 118, \mathrm{KCl} 4.7, \mathrm{MgCl}_{2} 1.16, \mathrm{CaCl}_{2} 2.0, \mathrm{NaH}_{2} \mathrm{PO}_{4}$ 1.16, glucose 14 , bovine serum albumin $2 \mathrm{mg} \cdot \mathrm{m}^{-1}$, soybean trypsin inhibitor $0.1 \mathrm{mg} \cdot \mathrm{ml}^{-1}$, HEPES 25 , BME amino acid mixture, glutamine $2, \mathrm{pH}$ adjusted to 7.3 with $\mathrm{NaOH} 1 \mathrm{~N}$, and oxygenated with $100 \% \mathrm{O}_{2}$ before use). Cells were stimulated in this buffer for $30 \mathrm{~min}$, and secreted amylase was expressed as percentage of total. Amylase was assayed with the method of Ceska et al.[20]. High $\mathrm{K}^{+}$solution was made by molar replacement of $\mathrm{Na}^{+}$.

\section{Intracellular calcium $\left(\left[\mathrm{Ca}^{2+}\right]_{\mathrm{c}}\right)$ measurement}

Sub-confluent AR4-2J cells were harvested, loaded with fura-2 AM ( $5 \mu \mathrm{M}, 37^{\circ} \mathrm{C}$ for $30 \mathrm{~min}$ ). Fura-2 loaded AR4-2J cells were sandwich positioned between layers of Biogel $\mathrm{P}_{2}$ beads (Bio Rad) and perifused with modified Ringer's solution (see above) in a quartz flow cuvette, and $\left[\mathrm{Ca}^{2+}\right] \mathrm{c}$ measured in a Spex DM3000CM spectrofluorometer, the ratios of F340/F380 were shown as indication of $\left[\mathrm{Ca}^{2+}\right] \mathrm{c}$ changes (Fig 1). In separate experiments, fura-2 loaded AR4-2J cells were resuspended and the suspension constantly stirred magnetically, F340 and F380 was measured in 
Spex DM3000CM. Since these cells were in suspension, at the end of the experiments cells were permeabilized for $\left[\mathrm{Ca}^{2+}\right]_{\mathrm{c}}$ calibration, and the fluorescence traces converted to $\left[\mathrm{Ca}^{2+}\right]_{\mathrm{c}}$ in $\mathrm{n} M$ (Fig 3).

\section{Materials}

Bay K 8644 was from CalBiochem (La Jolla, CA, USA). $\omega$-Conotoxin GVIA, $\omega$-agatoxin IVA were from Peptide Institute Inc. (Osaka, Japan). Fura-2 AM was from Molecular Probes (Portland, OR, USA).

\section{RESULTS}

High potassium induced increases in $\left[\mathrm{Ca}^{2+}\right]_{c}$

The fact that high potassium induced depolarization increased $\left[\mathrm{Ca}^{2+}\right]_{\mathrm{c}}$ in perifused AR4-2J cells (Fig 1) indicates that AR4-2J cells are excitable cells. In these experiments, AR4-2J cells were positioned into the light path of the Spex DM3000CM spectrofluorometer and continuously perifused with modified Ringer's solution at a flow rate of $1 \mathrm{ml} . \mathrm{min}^{-1}$.. High potassium pulse $(100 \mathrm{mM})$ was given at indicated time, pulse duration ranged from $2 \mathrm{sec}$ to $1 \mathrm{~min}$. From these experiments, it is obvious that potassium dose dependently increased $\left[\mathrm{Ca}^{2+}\right]_{\mathrm{c}}$. What is significant is that an 1 min pulse did not necessarily caused a larger increase in $\left[\mathrm{Ca}^{2+}\right]_{\mathrm{c}}$ than a $30 \mathrm{sec}$ pulse, indicating that large and fast increase in $\left[\mathrm{Ca}^{2+}\right]_{\mathrm{c}}$ may desensitize the

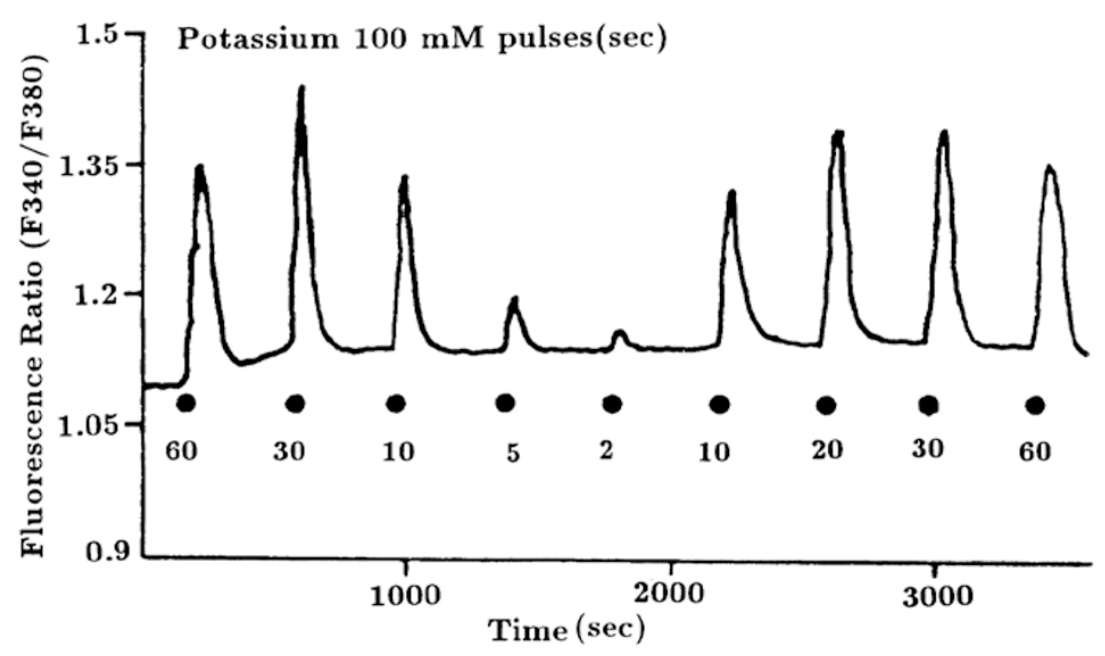

Fig 1. High potassium $(100 \mathrm{mM})$ pulses induced increases in $\left[\mathrm{Ca}^{2+}\right]_{\mathrm{c}}$ in perifused AR4-2J cells. Potassium pulses (100 $\mathrm{mM}$ ) of indicated duration (in sec) were given and increases in $\left[\mathrm{Ca}^{2+}\right]_{\mathrm{c}}$ were recorded as ratios of fura-2 fluorescence F340/F380. Trace is representative of 4 similar experiments. 
$\mathrm{Ca}^{2+}$ channels and amylase secretion in AR4-2J cells

voltage-dependent calcium channels, even on this macroscopical scale. This doseresponse relationship conforms to the general bell-shaped dose-response curve for amylase secretion in the exocrine pancreatic acinar cells[21].

\section{High potassium stimulated amylase secretion in a dose-, and time-dependent manner}

In AR4-2J cells, as in other secretory cells, the direct consequence of an increase in $\left[\mathrm{Ca}^{2+}\right]_{\mathrm{c}}$ is the stimulation of secretion, of amylase in this case. Indeed, high potassium (100 $\mathrm{mM}$ ) caused significant increase in amylase secretion (Fig 2). The increase in amylase secretion was a gradual process, the fastest secretion occurred within the first min (Fig 2A), and the rate gradually sloped off with time. This profile bears comparison with secretion triggered by normal secretagogues such as cholecystokinin.
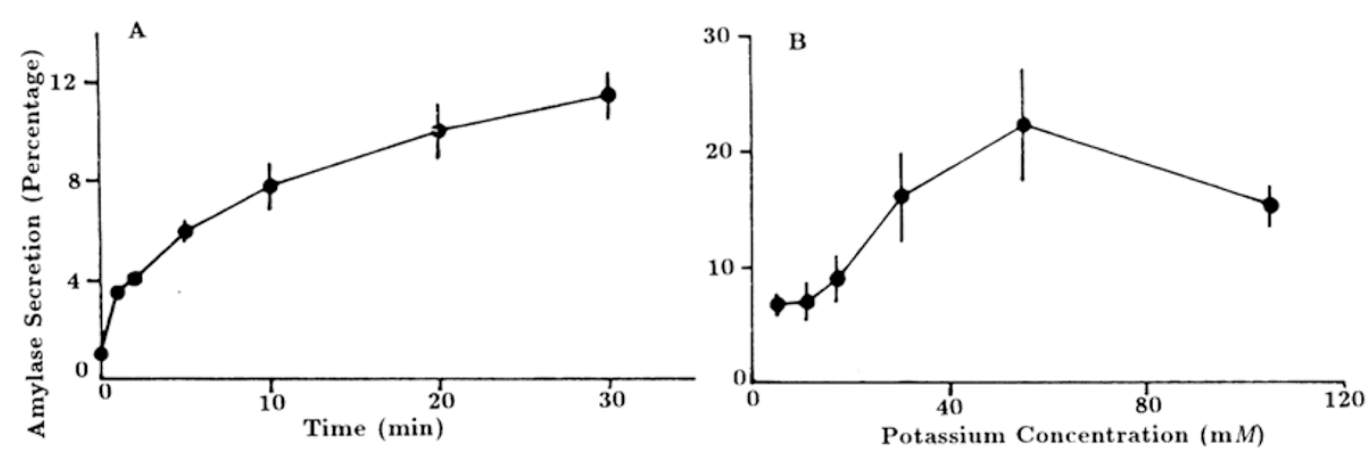

Fig 2. High potassium induced amylase secretion from adherent AR4-2J cells.
A. Time-dependence. Potassium $100 \mathrm{mM}$ was added to each culture well, and amylase secreted over the indicated time period expressed as percentage of total content present in cells before stimulation. $n=3$.
B. Concentration-dependence. Potassium of indicated concentration was added to each culture well, and amylase secreted in 30 min expressed as per- centage of total content present in cells before stimulation. $n=3$. Data are presented as $\mathrm{m} \pm$ sem.

Amylase secretion induced by high potassium depolarization also depended on the concentration of potassium used (Fig 2B). At $\mathrm{K}^{+} 11 \mathrm{mM}$ (it was $5 \mathrm{mM}$ in control), no obvious secretion was observed. Stimulation of secretion was seen only when $\mathrm{K}^{+}$had been raised to $17 \mathrm{mM}$. Significant stimulation was achieved with a concentration of $30 \mathrm{mM}$. Maximal stimulation was seen at $55 \mathrm{mM}$. As with physiological secretagogues, $\mathrm{K}^{+}$stimulation of amylase secretion also conforms to the bell-shaped dose-response curve. Supra-maximal $\mathrm{K}^{+}$concentration of $105 \mathrm{mM}$ induced a supramaximal inhibition. Therefore $55 \mathrm{mM}$ was needed for maximal stimulation, higher 
concentrations do not necessarily get higher amount of amylase secreted.

\section{Voltage-dependent calcium channel types involved in high potassium-induced increases in $\left[\mathrm{Ca}^{2+}\right]_{c}$}

To test what types of calcium channels were activated by high potassium depolarization, the effects of selective calcium channel antagonists on high potassium depolarization induced increases in $\left[\mathrm{Ca}^{2+}\right]_{\mathrm{c}}$ were investigated. The involvement of the L-type channels was examined with the dihydropyridine antagonist nifedipine, whereas $\omega$-conotoxin GVIA and $\omega$-agatoxin IVA were used to selectively block the $\mathrm{N}$ - and the P-types respectively. Fig 3 shows that $\mathrm{KC} 155 \mathrm{mM}$ induced marked increase in $\left[\mathrm{Ca}^{2+}\right]_{\mathrm{c}}$. This increase was significantly inhibited by the L-type antagonist nifedipine, the N-type antagonist $\omega$-conotoxin GVIA decreased $\left[\mathrm{Ca}^{2+}\right]_{\mathrm{c}}$ increase further (Fig 3A). Similarly, after inhibition by nifedipine, the P-type antagonist $\omega$ agatoxin IVA was able to decrease $\left[\mathrm{Ca}^{2+}\right]_{\mathrm{c}}$ further also (Fig 3B). From Fig 3, it is obvious that nifedipine had the greatest inhibitory effect; $\omega$-conotoxin GVIA although exhibited obvious inhibition, it was less effective than $\omega$-agatoxin IVA.

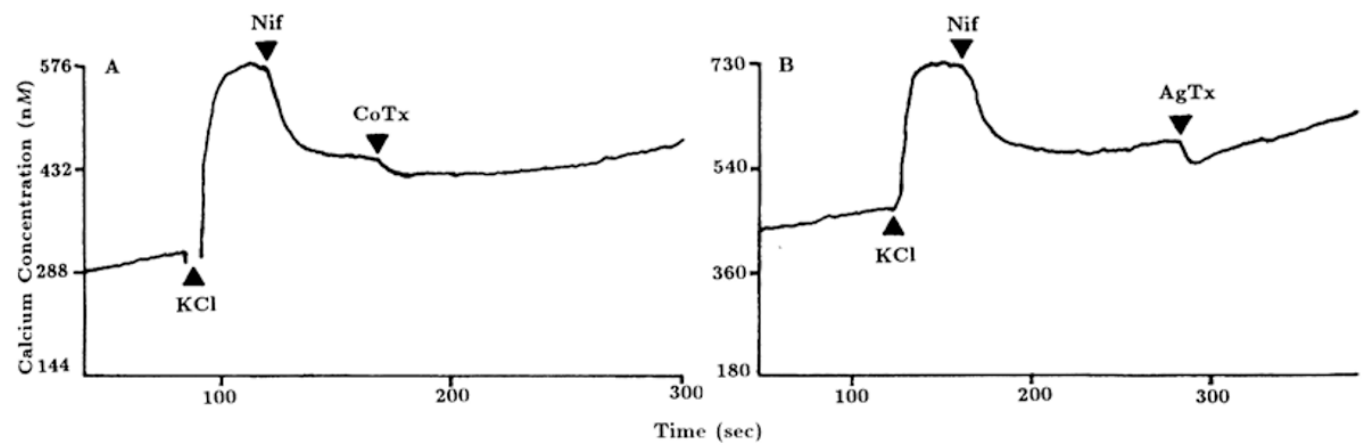

Fig 3. Inhibition of high potassium-induced increases in $\left[\mathrm{Ca}^{2+}\right]_{\mathrm{c}}$ by different calcium antagonists. F340 and F380 of Fura-2 loaded AR4-2J cells in suspension was monitored continuously and subsequently converted into $\left[\mathrm{Ca}^{2+}\right]_{\mathrm{c}}$ in $\mathrm{nM}$. Cells were first depolarized with KC1 $55 \mathrm{mM}$. This was followed by sequential additions of nifedipine $10 \mu M$ and $\omega$-conotoxin GVIA $1 \mu M$ (A), or nifedipine $10 \mu M$ and $\omega$-agatoxin IVA $100 \mathrm{n} M(\mathrm{~B})$. These traces are representative of a number of experiments, with a total number of treatments as follows: nifedipine, 23; $\omega$-conotoxin GVIA, 11; $\omega$-agatoxin IVA, 10. Nif, nifedipine; CoTx, $\omega$-conotoxin GVIA; AgTx, $\omega$-agatoxin IVA.

Voltage-dependent calcium channel types involved in high potassium-induced amylase secretion

The involvement of three types of voltage-dependent calcium channels in high 
potassium induced amylase secretion was examined. None of the type specific antagonists seemed to have any effect by itself $(P>0.05, n=3-4)$. It is apparent that the L-type accounted for most of amylase secreted, nifedipine decreased $55 \mathrm{mM}$ $\mathrm{K}^{+}$induced secretion completely back to control levels $(\mathrm{P}<0.05, \mathrm{n}=3$ ) (Fig $4 \mathrm{~A})$. Whereas $\omega$-conotoxin GVIA was completely without effect $(\mathrm{P}>0.05, \mathrm{n}=4)$ (Fig $4 \mathrm{~B})$, $\omega$-agatoxin IVA had only neglegible effect $(P>0.05, n=3)$ (Fig $4 \mathrm{C})$.

Fig 4. Inhibition of high potassium- induced amylase secretion by voltagedependent calcium channel antagonists. For each set of experiments, vesicle (control), potassium $55 \mathrm{mM}$, antagonist (nifedipine $10 \mu M, \omega$-conotoxin GVIA $1 \mu M$, $\omega$-agatoxin IVA $100 \mathrm{nM}$ ), or potassium $55 \mathrm{mM}$ plus antagonist was added to each culture well respectively, and amylase secreted in $30 \mathrm{~min}$ expressed as percentage of total present in cells before experiment. In $\mathrm{A}, \mathrm{n}=3$; in $\mathrm{B}, \mathrm{n}-4$; in $\mathrm{C}, \mathrm{n}=3$. Nif, nifedip-

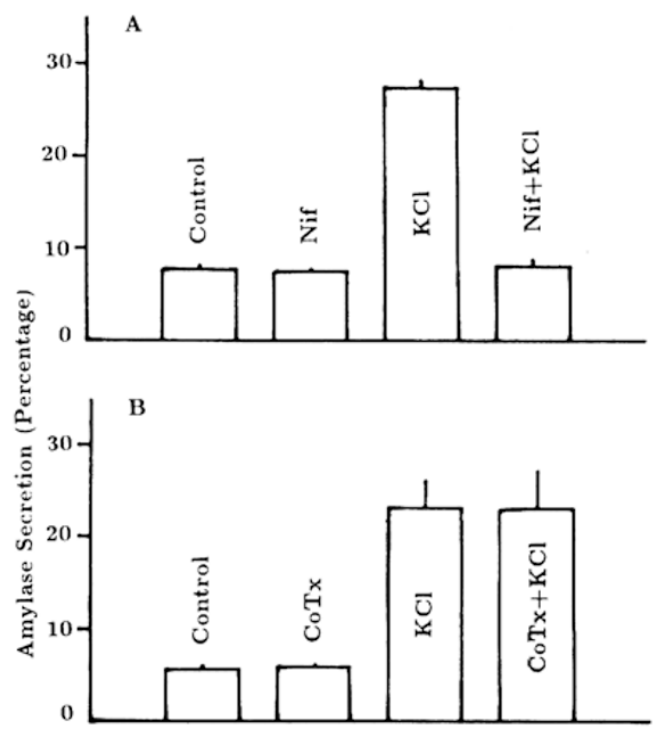
ine; CoTx, $\omega$-conotoxin GVIA; AgTx, $\omega$-agatoxin IVA. Data are presented as $\mathrm{m} \pm \mathrm{sem}$.

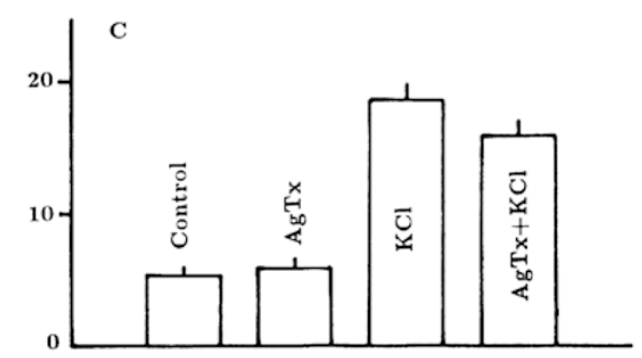

\section{DISCUSSION}

In this study, it was found that high potassium depolarization could: 1) increase $\left[\mathrm{Ca}^{2+}\right]_{\mathrm{c}}$ in a dose-dependent manner; 2) stimulate amylase secretion in a time- and concentration-dependent fashion. High potassium by depolarizing the plasma membrane, activates the voltage-dependent calcium channels. Openning of the voltagedependent calcium channels leads to $\mathrm{Ca}^{2+}$ influx resulting in a net increase in $\left[\mathrm{Ca}^{2+}\right]_{\mathrm{c}}$ which may in turn stimulate amylase secretion. High potassium induced increases in intracellular calcium were blocked by the voltage-dependent calcium channel an- 
tagonists with an order of potency: nifedipine $>\omega$-agatoxin IVA $>\omega$-conotoxin GVIA. In contrast, high potassium depolarization induced amylase secretion was completely abolished by the L-type calcium channel antagonist nifedipine, the Ptype antagonist $\omega$-agatoxin IVA had little effect, whereas the $\mathrm{N}$-type antagonist $\omega$-conotoxin GVIA was completely without effect. These data indicate that there are at least three types ( $\mathrm{L}, \mathrm{P}$, and $\mathrm{N}$ ) of voltage-dependent calcium channels in the exocrine pancreatic acinar cell line AR4-2J, but the L type accounts for nearly all of the amylase secreted during high potassium depolarization. Therefore AR4-2J cell line is not only a model for studying the secretory mechanisms of non-excitable cells, but could also serve as a convenient model for excitable cells.

The fact that both high potassium induced increase in $\left[\mathrm{Ca}^{2+}\right]_{c}$, and amylase secretion conforms to the bell-shaped dose-response curve is of much interest. This is different from stimulation by secretagogues[21, 22]. In the case of high potassium, supra-maximal inhibition of amylase secretion may be due to a supra-maximal inhibition of $\left[\mathrm{Ca}^{2+}\right]_{\mathrm{c}}$ increases. Whereas in the case of secretagogue induced amylase secretion, $\left[\mathrm{Ca}^{2+}\right]_{\mathrm{c}}$ increases generally do not conform to the bell-shaped dose-response curve, with supra-maximal stimulation resulting in an elevated plateau increase in $\left[\mathrm{Ca}^{2+}\right]_{\mathrm{c}}[22,23]$.

The difference in the dose-response curves in $\left[\mathrm{Ca}^{2+}\right]_{\mathrm{c}}$ increases induced by potassium depolarization and by secretagogues may provide a useful foothold for detailed investigation into the intriguing phenomenon of supra-maximal inhibition induced by secretagogues. Because in the former case supra-maximal inhibition in calcium increase may partly account for the supra-maximal inhibition in amylase secretion.

Judging from the experiments with calcium channel antagonists nifedipine, $\omega$ conotoxin GVIA and $\omega$-agatoxin IVA, it was mainly the L-type calcium channels that were involved in high potassium induced amylase secretion. Recently, it was found that in pancreatic B cells, L-type calcium channels co-localize with insulincontaining secretory granules[24]. Calcium-dependent exocytosis has been proposed to be regulated by a SNARE complex composed of secretory vesicle membrane proteins v-SNARE (synaptobrevin, synaptotagmin) and plasma membrane proteins t-SNARE (syntaxin, SNAP-25)[25]. There is evidence that both L- and N-type calcium channels can directly interact with the SNARE complex proteins syntaxin and SNAP-25[26, 27]. Whether in AR4-2J cells, L-type calcium channels would, like in other excitable cells, directly regulate the exocytotic SNARE complex will remain an open question at the present time. On the other hand, cytosolic calcium increase in AR4-2J cells by calcium influx through voltage-dependent calcium channels may, like in normal pancreatic acinar cells which are non-excitable, stimulate amylase secretion through the activation of calcium/calmodulin-dependent protein kinase II[28]. 
$\mathrm{Ca}^{2+}$ channels and amylase secretion in AR4-2J cells

\section{ACKNOWLEDGEMENT}

I thank my students who have kept me cheered up at this biomedical research post in an agricultural setting. I especially enjoyed he weekly Jorunal Club which gave me a chance to keep my English sharp. This work was supported by The Natural Science Foundation of China (Grant number:39670269, to ZJC).

\section{REFERENCES}

[1] Longnecker DS, Lilja HS, French J, Kuhlmann E, Noll W. Transplantation of azaserine-induced carcinomas of pancreas in rats. Cancer Lett 1979; 7:197-202.

[2] Jessop NW, Hay RJ. Characteristics of two rat pancreatic exocrine cell lines derived from transplantable tumors. In Vitro 1980; 16:212.

[3] Womack MD, Hanley MR, Jessell TM. Functional substance P receptors on a rat pancreatic cell line. J Neurosci 1985; 5:3370-8.

[4] Lambert M, Bui ND, Christophe J. Functional and molecular characterization of CCK receptors in the rat pancreatic acinar cell line AR4-2J. Regulat Peptide 1991; 32:151-67.

[5] Viguerie N, Esteve J-P, Susini C, Logsdon CD, Vaysse N, Ribet A. Dexamethasone effects on somatostatin receptors in pancreatic acinar AR4-2J cells. Biochem Biophys Res Commun 1987; 147:942-8.

[6] Viguerie N, Tahiri-Jouti N, Esteve J-P, Clerc P, Logsdon C, Svoboda M, Susini C, Vaysse N, Ribet A. Functional somatostatin receptors on a rat pancreatic acinar cell line. Am J Physiol 1988; 255:Gl13-20.

[7] Scemama JL, Robberecht P, Waelbroeck M, De Neef P, Pradayrol L, Vaysse N, Christophe J. CCK and gastrin inhibit adenylate cylcase activity through a pertusis toxin-sensitive mechanism in the tumoral rat pancreatic acinar cell line AR4-2J. FEBS Lett 1988; 242:61-4.

[8] Menniti FS, Takemura H, Oliver K, Putney JW, Jr. Different modes of regulation for receptors activating phosphorylipase $\mathrm{C}$ in the rat pancreatoma cell line AR4-2J. Mol Pharmacol 1991; 40:727-33.

[9] Raymond MJ, Rosenzweig SA. Vasoactive intestinal peptide receptors on AR42J rat pancreatic acinar cells. Biochem Biophys Res Commun 1991; 179:176-82.

[10] Huang Y, Fisher JE, Balasubramaniam A. Amylin mobilizes $\left[\mathrm{Ca}^{2+}\right]_{i}$ and stimulates the release of pancreatic digestive enzymes from rat acinar AR4-2J cells: evidence for an exclusive receptor system of amylin. Peptides 1996; 17:497-502.

[11] Petersen OH, Findlay I. Electrophysiology of the pancreas. Physiol Rev 1987; 67:1054-116.

[12] Petersen OH, Gallacher DV. Electrophysiology of pancreatic and salivary acinar cells. Ann Rev Physiol 1988; 50:65-80.

[13] Kusano K, Gainer H. Whole cell current analysis of pancreatic acinar AR4-2J cells. I. Voltageand $\mathrm{Ca}^{2+}$-activated currents. Am J Physioly 1991; 260:C934-48.

[14] Rosewicz S, Riecken EO, Wiedenmann B. The amphicrine pancreatic cell line AR42J: a model system for combined studies on exocrine and endocrine secretion. Clin Invest 1992; 70:205-9.

[15] Rosewicz S, Vogt D, Harth N, Grand C, Franke WW, Ruppert S, Schweitzer E, Riecken EO, Wiedenmann B. An amphicrine pancreatic cell line: AR4-2J cells combine exocrine and neuroendocrine cell properties. Eur J Cell Biol 1992; 59:80-91.

[16] Ahnert-Hilger G, Wiedenmann B. The amphicrine pancreatic cell line, AR42J, secretes GABA and amylase by separate regulated pathways. FEBS Letters 1992; 314:41-4.

[17] Gaur S, Newcomb R, Rivnay B, Bell JR, Yamashiro D, Ramachandran J, Miljanich GP. Calcium channel antagonist peptide defines several components of transmitter release in the hippocampus. Neuropharmacol 1994; 33:1211-9. 
[18] Turner TJ, Lambert RA, Dunlop K. Characterization of presynaptic calcium channels with $\omega$-conotoxin MVIIA and $\omega$-grammotoxin SIA: role for a resistant calcium channel type in neurosecretion. Mol Pharmacol 1995; 47:348-53.

[19] Matthews EK, Cui ZJ. Photodynamic action of sulphonated aluminium phthalocyanine (SALPC) on AR4-2J cells, a carcinoma cell line of rat exocrine pancreas. Br J Cancer 1990; 61:695-701.

[20] Ceska M, Birath K, Brown B. A new and rapid method for the clinical determination of a amylase activities in human serum and urine. Optimal conditions. Clin Chem Acta 1969; 26:437-44.

[21] Rogers J, Hughes RG, Matthews EK. Cyclic GMP inhibits protein kinase C-mediated secretion in rat pancreatic acini. J Biol Chem 1988; 263:3713-9.

[22] Rowley WH, Sato S, Huang SC, Collado-Escobar DM, Beaven LH, Wang MA, Martinez J, Gardner JD, Jensen RT. Cholecystokinin-induced formation of inositol phosphates in pancreatic acini. Am J Physiol 1990; 259:G655-65.

[23] Sato S, Stark HA, Martinez J, Beaven MA, Jensen RT, Gardner JD. Receptor occupation, calcium mobilization and amylase secretion in pancreatic acini: effect of CCK-JMV-180. Am J Physiol 1989; 257:G202-9.

[24] Bokvist K, Eliassen L, Ammala C, Renstrom E, Bosman P. Co-localization of L-type $\mathrm{Ca}^{2+}$ channels and insulin-containing secretory granules and its significance for the initiation of exocytosis in mouse pancreatic B-cells. EMBO J 1995; 14:50-7.

[25] Cui ZJ. Molecular mechanisms of exocytosis. Prog Physiol Sci (Beijing) 1996; 27:233-7.

[26] Sheng Z-H, Rettig J, Cook T, Catterall WA. Calcium-dependent interaction of N-type calcium channels with the synaptic core complex. Nature 1996; 379:451-4.

[27] Wiser O, Bennett MK, Atlas D. Functional interaction of syntaxin and SNAP-25 with voltagedependent L- and N-type $\mathrm{Ca}^{2+}$ channels. EMBO J 1996; 15:4100-10.

[28] Cui ZJ. Muscarinic stimulation of calcium/calmodulin -dependent protein kinase II in isolated rat pancreatic acini. Acta Pharmacol Sinica 1997; 28:255-8.

Received Nov-10-1997. Revised Jan-20-1998. ～Accepted Jan-21-1998. 